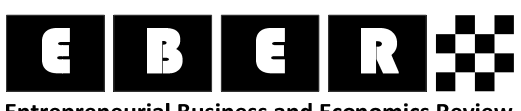

Entrepreneurial Business and Economics Review

2014, Vol. 2, No. 2

\title{
Editorial: Globalisation of Economies and Industries
}

Globalisation as the widespread political, economic and cultural process has become a highly popular research topic since the end of the 20th century. The advancement of international regulations, the emergence of such institutions as the World Trade Organization (WTO) and the improvements in transportation as well as information and communication technologies (ICTS) have made states (with their political regimes, economies and cultures) interdependent to a scale never heard before. Therefore, we might think that we live in a unique and special moment.

On the other hand, however, we should remember that our post-World War II history has been founded on the principle of interdependency and international collaboration. The Preamble to the Charter of the United Nations signed in San Francisco stated that some of the ultimate goals of the organization were: "to promote social progress and better standards of life in larger freedom" and "to employ international machinery for the promotion of the economic and social advancement of all peoples". Of course, in 1945 no one could have considered signing the Charter as the beginning of the process of globalisation, but it is worth to remember that investigating economy always calls for broader perspective.

At the beginning of the 21st century we also experience some drawbacks of globalisation. Yes, it "promotes economic and social advancement", but the progress is not evenly distributes and not "all peoples" enjoy the benefits of globalisation. Growing interdependency has also brought greater competition, this time reaching much further that just neighbouring countries. "Competing with everyone from everywhere for everything", as says the title of the book published quite recently, cannot be beneficial for all nations and all people (Sirkin, Hemerling \& Bhattacharya, 2008). After joining the European Union, the economies of Central and Eastern Europe have become even more exposed to the economic and market challenges of global scale (Klich, 2013; Szarucki, 2013). Therefore, we decided to focus this issue of our journal on exploring the Globalisation of Economies and Industries.

Martin Gjelsvik in the article, Capabilities for innovation in a globalizing world: from nearby or at a distance?, investigates innovation capabilities of Norwegian firms in the context of their global and/or local activity. While employing the concept of clusters, the author comes to rather astonishing conclusions: regional clusters sometimes might slow down technological advancement of businesses.

Robert Włodarczyk in the article, Is there a global currency war?, focuses on the issue that might define both positive and negative outcomes of globalisation. States with powerful economies, thanks to their national banks, can use exchange rates of national 
currencies as an efficient means of securing and promoting economic growth. Such actions have a tremendous impact on weaker economies that do not have enough resources to react to hostile actions of the powers.

Eduard Nežinský and Elena Fifeková in their paper of simple and promising title, The V4: A Decade after the EU entry, explore that impact of EU enlargement and regulations adjustments on the technological change and economic catch-up of the Visegrad group countries. The authors suggest, employ, and test interesting tools for assessing and evaluating the pace of economic progress of the V4 states.

Implementation of international standards for environmental management in Visegrad countries: a Comparative analysis by Maria Urbaniec focuses on the issue already mentioned in Nežinský and Fifeková's text: ecoeffciency of enterprises in V4 states. Environmental management is a special field of investigations because it combines global influence of International Organization for Standardization (with famous ISO 14000 standards) and EU voluntary regulations. The author compares the impact both solutions have on V4 companies and managerial approach.

Monika Płaziak and Anna Irena Szymańska present Construction sector in the Czech Republic and Poland-Focus on the housing segment in selected regions. As the authors rightly point out, the global 2008 crisis had a tremendous impact on construction sector in the Czech Republic and Poland. However, both countries performed in a bit different way during post-2008 period, therefore the analysis of Płaziak and Szymańska looks for the explanation of the difference.

Alternative approaches in evaluating the EU SME policy: Answers to the Question of Impact and Legitimization by Robert K. Gruenwald explores one of the key components of EU economic policies. While small and medium enterprises have become an important issue in the context of globalisation, it is still not resolved how to evaluate the effects of adopted policies. The answer to such a question is vital for assessing and adjusting the economic policy.

We do hope that the articles presented in this issue will inspire further research. Moreover, we would be happy to publish the results of future studies in the upcoming issues of our Journal.

\section{Radosław Rybkowski Krzysztof Wach}

Issue Editors

\section{REFERENCES}

Klich, J. (2013). Editorial: Modern Challenges for International Business in Europe. Entrepreneurial Business and Economics Review, 1(2), 5-6.

Sirkin, H., Hemerling, J. \& Bhattacharya A., (2008), Globality: Competing with Everyone from Everywhere for Everything. New York NY: The Boston Consulting Group Inc.

Szarucki, M. (2013). Editorial: Modern Challenges for Business and Economy in CEE Countries. Entrepreneurial Business and Economics Review, 1(4), 5-6. 